\title{
Inngifte gir økt risiko for hjernesykdommer
}

\author{
Risikoen for fremadskridende hjerne- \\ sykdommer hos norsk-pakistanske \\ barn er sju ganger høyere enn hos \\ norske barn.
}

Det er konklusjonen i en undersøkelse fra Oslo om progredierende encefalopatier (1). Studien omfattet 65 barn med over 20 ulike årsaksdiagnoser, hvorav mange autosomalt resessive metabolske sykdommer. Slike tilstander kjennetegnes av høy grad av morbiditet og mortalitet og komplisert diagnostikk. Pasientene ble inndelt etter geografisk bakgrunn og foreldrenes inngiftestatus. Inngifte ble definert som ekteskap mellom fetter og kusine eller enda nærmere grad av slektskap. Søskenbarnekteskap forekommer hos $40-45 \%$ av foreldrepar med pakistansk bakgrunn bosatt i Norge, andelen søskenbarnekteskap hos norske foreldrepar er $0,07 \%$.

Det ble funnet 30 pasienter per 79704 personår med pakistansk bakgrunn og 35 norske pasienter per 658932 personår. Insidensratene på henholdsvis 37,6 og 5,3 per 100000 personår ga en insidensrateratio (IRR) på 7,1 (95\% KI 4,2-11,9). Tilsvarende tall for barn av inngiftede versus ikke-inngiftede foreldre med pakistansk bakgrunn var 3,2 (95\% KI 1,4-7,2).

Mellom norsk-pakistanske barn med inngiftede foreldre og barn av norsk opprinnelse var tallet 11,2 .

Dette er den første studien der risikoen for progredierende encefalopatier forbundet med inngifte blir tallfestet. Selv om fore- komsten av slike sykdommer er relativt lav, selv i befolkningsgrupper der inngifteandelen er høy, føyer den seg inn i rekken av undersøkelser som konkluderer med at inngifte medfører signifikant økt risiko for genetisk betingede sykdommer.

\section{Petter Strømme}

petter.stromme@medisin.uio.no

Barneavdeling for nevrofag

Kvinne- og barnklinikken

Oslo universitetssykehus, Ullevål

\section{Litteratur \\ 1. Strømme P, Suren P, Kanavin OJ et al. Parental consanguinity is associated with a seven-fold increased risk of progressive encephalopathy: a cohort study from Oslo, Norway. Eur J Paediatr Neurol 2010; 14: 138-45.}

\section{Metformin og $\mathbf{B}_{12}$-mangel}

Det er kjent at metformin induserer malabsorpsjon av vitamin $B_{12}$, og kan også være assosiert med redusert folatkonsentrasjon. Dette kan igjen føre til økt konsentrasjon av homocystein. Belgiske og nederlandske forskere har nå undersøkt effekten av metformin på nivåene av vitamin $\mathrm{B}_{12}$, folat og homocystein hos pasienter med type 2-diabetes som ble behandlet med insulin (BMJ 2010; 340: c2181).

390 pasienter fikk enten $850 \mathrm{mg}$ metformin eller placebo tre ganger daglig i 4,3 år. Studien viste at metformin ga økt risiko for vitamin $B_{12}$-mangel og førte til økt konsentrasjon av homocystein. Den negative effekten ble større over tid. Etter justering for kroppsmasseindeks og røyking ble det ikke påvist reduksjon i folatkonsentrasjonen.

\section{Pregabalin ved rastløse bein}

Ved rastløse bein kan man få terapeutisk effekt av pregabalin på både sensoriske og motoriske symptomer, ifølge en ny studie (Neurology 2010; 74: 1897-904).

Studien var dobbeltblindet og placebokontrollert og omfattet 98 pasienter med idiopatisk rastløse bein. De som hadde fått pregabalin, hadde større bedring enn placebopasientene målt på skalaen International Restless Legs Scale (63\% versus 38\%). Den gjennomsnittlige effektive dose for pregabalin var $322,5 \mathrm{mg}$ per dag. Bivirkningene var milde, men hyppige, og omfattet ustabilitet, sløvhet om dagen og hodepine.

\section{Behandling av diabetes hos minoriteter}

\author{
Hos minoritetspasienter med type 2- \\ diabetes er det tidligere sykdoms- \\ debut og dårligere glykemisk kontroll \\ enn hos norske.
}

Dette er hovedfunnet i en norsk studie om kvaliteten på diabetesomsorgen i fem etniske grupper i 2005 (1). 1653 pasienter med type 2-diabetes som gikk til kontroll hos 49 fastleger i Groruddalen var inkludert. De fem etniske gruppene hadde opprinnelse fra Norge (1 129 personer), det indiske subkontinent (322 personer), ØstAsia (54 personer), Midtøsten og NordAfrika (81 personer) og andre regioner samlet (67 personer).

Gjennomsnittsalder ved diagnosetidspunktet var for de norske 59,7 år, i minoritetsgruppene var den 8-15 år lavere. I alle grupper fikk over $85 \%$ målt $\mathrm{HbA}_{1 \mathrm{c}}$, blodtrykk og s-kolesterol ved årskontrollen. En større andel av minoritetsgruppene enn av de norske pasientene fikk glukosesenkende behandling ( $\geq 79 \% \operatorname{mot} 72 \%$ ). Gjennomsnittlig $\mathrm{HbA}_{1 \mathrm{c}}$-nivå var $6,9 \%$ for de norske og varierte mellom 7,3\% og 7,6\% for minoritetsgruppene etter justering for alder, kjønn, sykdomsvarighet, legesenter og lege.

Andelen med dårlig glykemisk kontroll $\left(\mathrm{HbA}_{1 \mathrm{c}}>9 \%\right)$ var $19,6 \%$ hos dem fra det indiske subkontinentet, 18,9\% hos dem fra Midtøsten og Nord-Afrika og 5,6\% hos de norske. Rundt $25 \%$ i de fleste gruppene oppnådde kombinert behandlingsmål $\left(\mathrm{HbA}_{1 \mathrm{c}} \leq 7,5 \%\right.$, systolisk blodtrykk $\leq 140 \mathrm{~mm} \mathrm{Hg}$, diastolisk

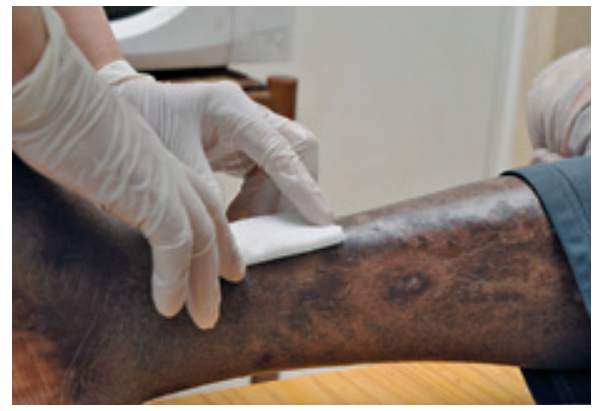

Illustrasjonsfoto @ Aubert/BSIP/GV-Press/ NordicPhotos

blodtrykk $\leq 85 \mathrm{~mm} \mathrm{Hg}$, s-kolesterol $\leq 5,0$ $\mathrm{mmol} / \mathrm{l})$.

Funnene viser at det var like god kvalitet på diabetesomsorgen i alle gruppene når det gjaldt undersøkelsesprosedyrer. Det er likevel viktig med tidlig diagnostikk, optimal glukosesenkende behandling og samarbeid med spesialister i omsorgen for minoritetspasienter som ikke når behandlingsmålene.

\section{Anh Thi Tran}

a.t.tran@medisin.uio.no

Universitetet i Oslo

\footnotetext{
Litteratur

1. Tran AT, Diep LM, Cooper JG et al. Quality of care for patients with type 2 diabetes in general practice according to patients' ethnic background: a cross-sectional study from Oslo, Norway. BMC Health Serv Res 2010; 10: 145.
} 